\title{
Impact of lowered curing temperature on the compressive strength of polymer-cement repair mortars
}

\author{
Damian Wojnowski ${ }^{1, *}$, Barbara Francke ${ }^{1}$ \\ ${ }^{1}$ Building Research Institute, Construction Materials Engineering Department, Filtrowa 1, 00-611 Warsaw, Poland
}

\begin{abstract}
This article discusses the results of tests regarding mechanical properties of polymer-cement repair mortars which were cured at a lowered temperature. The assessment was based on compressive strength tests of three PCC repair mortars available on the market. The tests were performed on samples cured at a temperature of $21^{\circ} \mathrm{C}$ and $8^{\circ} \mathrm{C}$ and following designed variable-temperature cycles. The tests showed a negative impact of lowered temperature present during curing of concrete repair mortars on these mortars' compressive strength. Repairing concrete structures during lowered temperatures may cause a drop in parameters considerably lowering the product's class. Extending the cure time for mortars applied and cured at low temperatures will cause these parameters to increase, but will not always allow to achieve values equal to those of samples cured in laboratory conditions.
\end{abstract}

\section{Introduction}

Repairs of concrete structures are done throughout the year, which in Poland's climate means that it is necessary to do them also at temperatures under $5^{\circ} \mathrm{C}$. This raises questions regarding the durability of repairs carried out at a lowered temperature. As repair works use materials based on completely different substances, e.g. polymer-cement, polymer, hydraulic mortars [1-3], the analysis of the problem should be performed separately for each of these groups. This article focuses on one of them, i.e. polymer-cement mortars. The polymer-cement group of repair mortars can further be divided based on the composition of the products, which has a direct influence on the recommended conditions of application. The division that is the most clear to a potential contractor is based on the principle of defining the minimum temperature for application of these products as equal to $+5^{\circ} \mathrm{C}$. This allows to classify the repair products into two groups: those used at temperatures above $+5^{\circ} \mathrm{C}$ and those possible to apply at temperatures lower than that. Performing repairs at a temperature lower than $1{ }^{\circ} \mathrm{C}$ is not permitted. According to market research, mortars accepted for use at temperatures lower than $5^{\circ} \mathrm{C}$ are available on custom order and the selection in this regard was very limited. Therefore, we must accept the fact that regardless of the ambient temperature, most repairs will be done using products intended to be used at a temperature above $5^{\circ} \mathrm{C}$. Due to the fact that properties of polymer-cement mortars are close to those of the wider group including cement mortars and concrete, some of the rules concerning the application of mortars reflect requirements set for concrete and $+5^{\circ} \mathrm{C}$ is also considered to be the minimum temperature for concrete works [3]. If this requirement is not met, the concrete should be protected against loss of heat [3-4]. In the analysed technical literature there was no clear answer to the question whether a sudden drop in temperature during repairs or during binding of completed layers negatively impacts repair mortars' mechanical properties. Assuming similarity to concrete, the knowledge related to these two similar groups of products was used in developing a test methodology for assessing strength properties of polymer-cement repair mortars. For concrete, technical literature often mentions that lowering temperature during its curing effects a decrease in the rate at which it gains strength. Concrete structures constructed in lowered temperature may never reach strength parameters equal to those curing in conditions similar to laboratory conditions, even when the cure time is extended [4-10]. In the case of polymercement mortars, there was only a small number of publications concerning their durability in the event of making repairs in extreme temperature conditions, which allows to assume that the problem is not fully explored and needs further research.

\section{Experimental programme}

The tests, the results of which are presented in this article, were aimed at assessing the impact of lowered temperature present during curing on the values of tested parameters. Comparative compressive strength tests were carried out for scenarios where the mortar was cured in laboratory conditions, at a lowered temperature as well as according to a preprogrammed variabletemperature cycles, simulating a sudden, unexpected drop in temperature at different moments of the cure process. As a result of temperature analysis from multiple years in selected regions of Poland, $8^{\circ} \mathrm{C}$ was

* Corresponding author: d.wojnowski@itb.pl 
adopted as the baseline lowered temperature. Considering that repair mortars are not allowed to be used at temperatures below $1^{\circ} \mathrm{C}$, the simulated cycles only lowered temperature to that value. The pattern of temperature change in the variable-temperature cycles is presented in figure 1 .

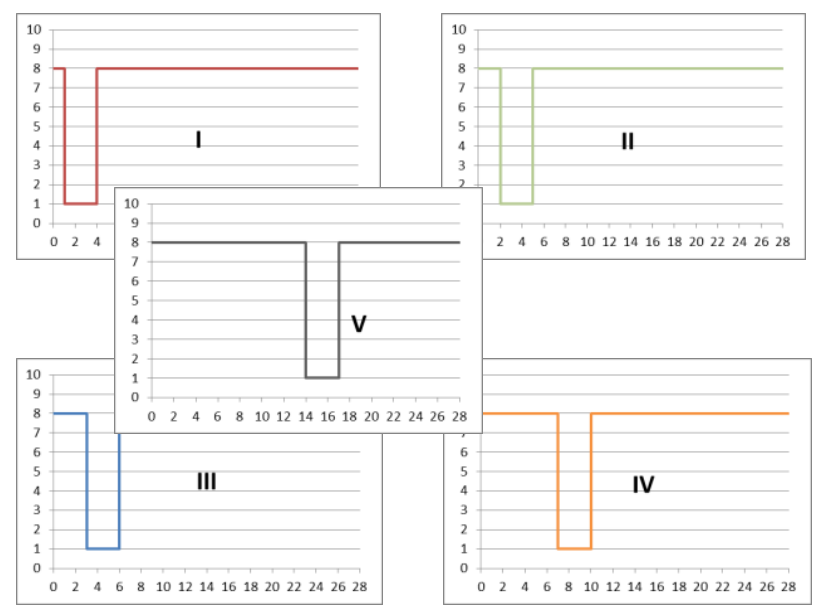

Fig.1. Process of sample curing for the compressive strength test using variable-temperature cycles

Three class R4 polymer-cement repair mortars were chosen for the tests. Two of them were produced by the same manufacturer, but with considerably different compositions (mortar $\mathrm{C}$ and $\mathrm{D}$ ); the third is a product from a different manufacturer (mortar B). All mortars consist of cement, aggregate and additions. Mortars C and $\mathrm{D}$ differ in the type of cement used, and type and quantity of additions. The ingredients of mortar B are not known in detail. In each case the recommended procedure of preparing the mixtures is different. All mortars have a common characteristic - they can be used in the temperature range $5-30^{\circ} \mathrm{C}$.

For the above repair mortars, strength gain over time was determined for scenarios where they were cured at $21^{\circ} \mathrm{C}, 8^{\circ}$, and under variable-temperature cycles the plan of which was shown in figure 1 .

Samples in the form of blocks with dimensions $40 \times 40 \times 160 \mathrm{~mm}$ were made according to the guidelines in the product data sheets. All samples were prepared by the same person, using the same method (same mixing time for any one mortar, the same method of compaction, etc.). All samples were prepared in laboratory conditions at a temperature of $(21 \pm 2)^{\circ} \mathrm{C}$ and relative humidity of $(60 \pm 10) \%$. In the case of samples cured at a lowered temperature, the temperature of mortars, water and the formwork was lowered down to $8^{\circ} \mathrm{C}$, then the samples were prepared in laboratory conditions in the shortest possible time, and shortly after preparation moved to an environmental chamber and stored at a temperature of $(8 \pm 1)^{\circ} \mathrm{C}$ and relative humidity of $(90 \pm 10) \%$. Samples cured at $(21 \pm 2)^{\circ} \mathrm{C}$ and $(60 \pm 10) \%$ relative humidity were left in the laboratory after preparation until the end of the cure time. The mortar samples subjected to variable-temperature cycles were prepared in the same way as those cured at $(8 \pm 1)^{\circ} \mathrm{C}$ and $(90 \pm 10) \%$ relative humidity, and at the right moment, depending on the cycle, placed for 3 days under temperature equal $(1 \pm 1)^{\circ} \mathrm{C}$. All samples were removed from the formwork 24 hours after preparation, and covered with foil for another 48 hours. In the further part of the article, for the sake of simplicity the samples cured in standard laboratory conditions are referred to as "cured at $21^{\circ} \mathrm{C}$ " and those cured under a lowered temperature - as "cured at $8^{\circ} \mathrm{C}$ ". The compressive strength tests were performed after 1, 2, 3, 7, 14, 21 and 28 days and additionally after 42 days in the case of samples cured at $8^{\circ} \mathrm{C}$, and compressive strength tests for samples cured under variable-temperature cycles were performed after the end of curing at $(1 \pm 1)^{\circ} \mathrm{C}$ and after 28 days.

\section{Results and discussion}

\subsection{Determining the progress of compressive strength for mortar samples cured at $21^{\circ} \mathrm{C}$ and $8^{\circ} \mathrm{C}$ in accordance with PN-EN 12190:2000}

The compressive strength test was performed according to standard PN-EN 12190:2000. Mortar B test samples cured at a lowered temperature reach a low strength after the first day of curing, but after the second day the mortar shows considerable improvement and increase in strength to over $10 \mathrm{MPa}$. A decrease in strength gain rate can be recorded after $3 \mathrm{rd}$ and then after 14th day of curing, after which the mortar's strength gain rate increases, and its strength reaches $39.4 \mathrm{MPa}$ on the 42nd day.

Mortar B samples cured in laboratory conditions achieved a considerably better strength value after the 1 st day of curing than the samples cured at lowered temperatures; their strength was 14.2 MPa. After the 3rd day of curing there is a noticeable drop of the strength gain rate, which drops again after 21 days of curing. After 28 days of curing the mortar reaches a strength of $53.3 \mathrm{MPa}$.

Mortar C samples after the 1st day of curing achieved a low strength value, under $5^{\circ} \mathrm{C}$. In subsequent days it showed a faster rate of strength gain, leading to a considerable rise in this parameter. The first drop of the compressive strength gain rate can be noticed after the 3rd day, and the next one after the 14th day of curing. Despite that, increase in compressive strength can be recorded until the end of the curing period analysed. The mortar ultimately reaches compressive strength equal to $48.7 \mathrm{MPa}$.

Mortar C samples cured in laboratory conditions reached significantly higher values than those cured at a lowered temperature. In this case the value obtained after one day of curing was considerably higher (almost six times). A high rate of strength gain was maintained until the 7th day. After that, the gain rate dropped, however the gain in strength continued and remained steady until the end of the analysed curing period, allowing to reach strength equal to $58.1 \mathrm{MPa}$ after 28th day of curing. This value is higher by $10 \mathrm{MPa}$ compared to that obtained in conditions of a lowered temperature after the maximum cure time, i.e. 42 days. 
Mortar D samples cured at a lowered temperature, similarly to samples of mortars B and C, reached a low strength after the first day, however after the second day the mortar's strength showed a considerable improvement, going up above $17 \mathrm{MPa}$. In the subsequent days this value gradually increased, reaching $51.7 \mathrm{MPa}$ on the 42th day. The highest rate of strength increase was recorded in the first three days, after which it diminishes. However, strength keeps rising until the end of the analysed curing period.

Mortar D samples cured in laboratory conditions, the same as B and C samples, reached significantly higher strength values than those recorded after the 1st day for samples cured at a lowered temperature - 23.4 MPa. A dynamic strength gain rate can be noticed until the 2 nd day of curing, which is when the rate drops and remains steady until the end of the analysed curing period (28 days). After that time, the mortar reached a strength of 52.4 MPa. Comparing the values obtained after maximum cure times in both cases, it can be concluded that extending the cure time for mortars cured at a lowered temperature allowed to obtain the same strength values as those displayed by mortar cured in laboratory conditions.
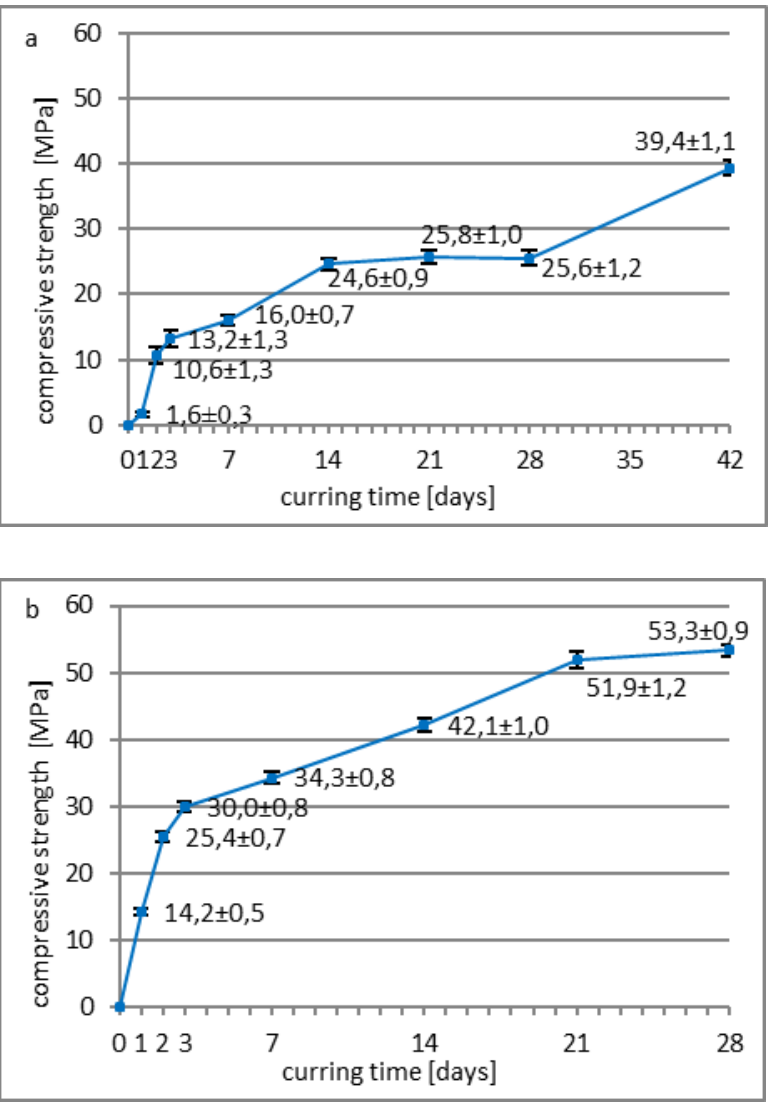
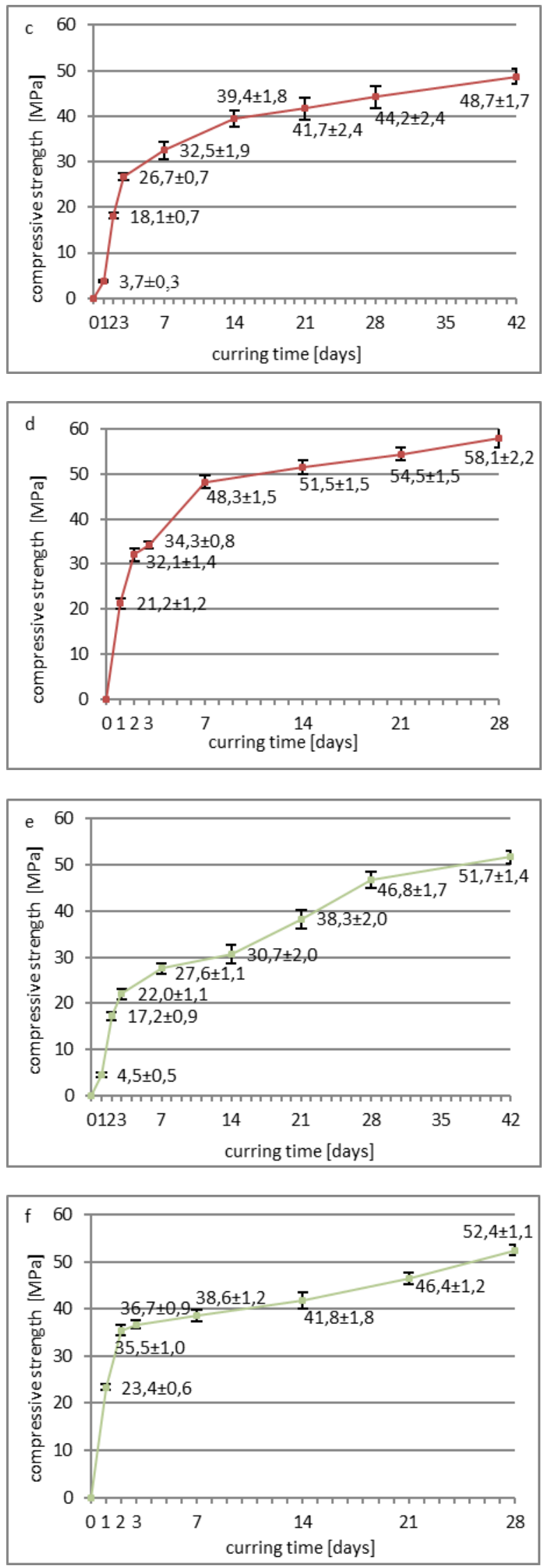

Fig. 2. Strength gain over time for $B, C$ and $D$ mortars cured at $8^{\circ} \mathrm{C}$ and $21^{\circ} \mathrm{C}$ a) B mortar cured at $8^{\circ} \mathrm{C}$, b) B mortar cured at $21^{\circ} \mathrm{C} \mathrm{c}$ ) $\mathrm{C}$ mortar cured at $8^{\circ} \mathrm{C}$, d) $\mathrm{C}$ mortar cured at $21^{\circ} \mathrm{C}$, e) D mortar cured at $8^{\circ} \mathrm{C}, \mathrm{f}$ ) $\mathrm{D}$ mortar cured at $21^{\circ} \mathrm{C}$ 


\subsection{Determining compressive strength for mortar samples subjected to variable- temperature cycles}

Analysing the test results obtained for B mortar subjected to variable-temperature cycles, it can be determined that despite the low value of compressive strength obtained after the 1st day, which was considerably lower than $5 \mathrm{MPa}$ (critical strength), lowering the temperature to $1^{\circ} \mathrm{C}$ did not affect the strength gain adversely. A negative influence of lowering the temperature to $1^{\circ} \mathrm{C}$ on strength gain rate did not occur in the other cases, i.e. if it is introduced after 2 , 3,7 and 14 days. However, differences can be noticed in the final strength values after 28th day of curing. The test results, compared to those from samples cured at $8^{\circ} \mathrm{C}$ the entire time are similar in cycle I, slightly lower in cycle II and III, higher in cycle IV, and considerably higher in cycle $\mathrm{V}$. A decrease of strength after storage at $1{ }^{\circ} \mathrm{C}$ was not recorded for any of the scenarios. Furthermore, after the period of storage at $1{ }^{\circ} \mathrm{C}$ ended and curing at $8^{\circ} \mathrm{C}$ was continued until the 28th day, each of the cases displayed an increase in strength.
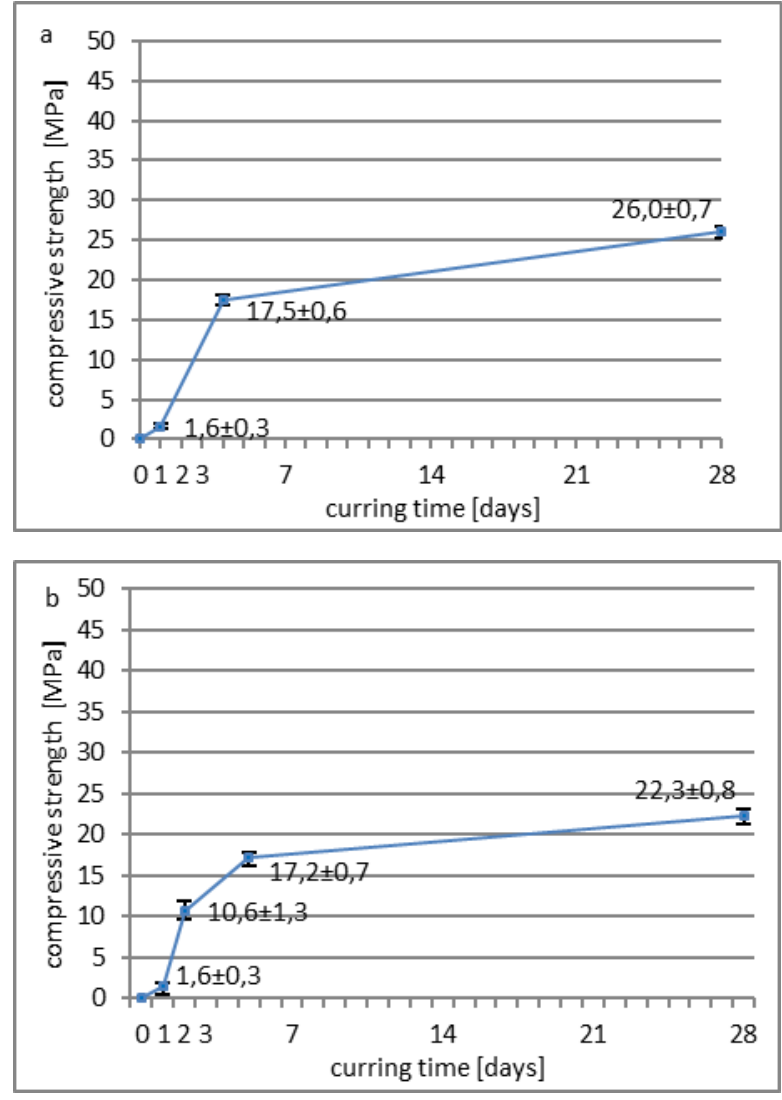
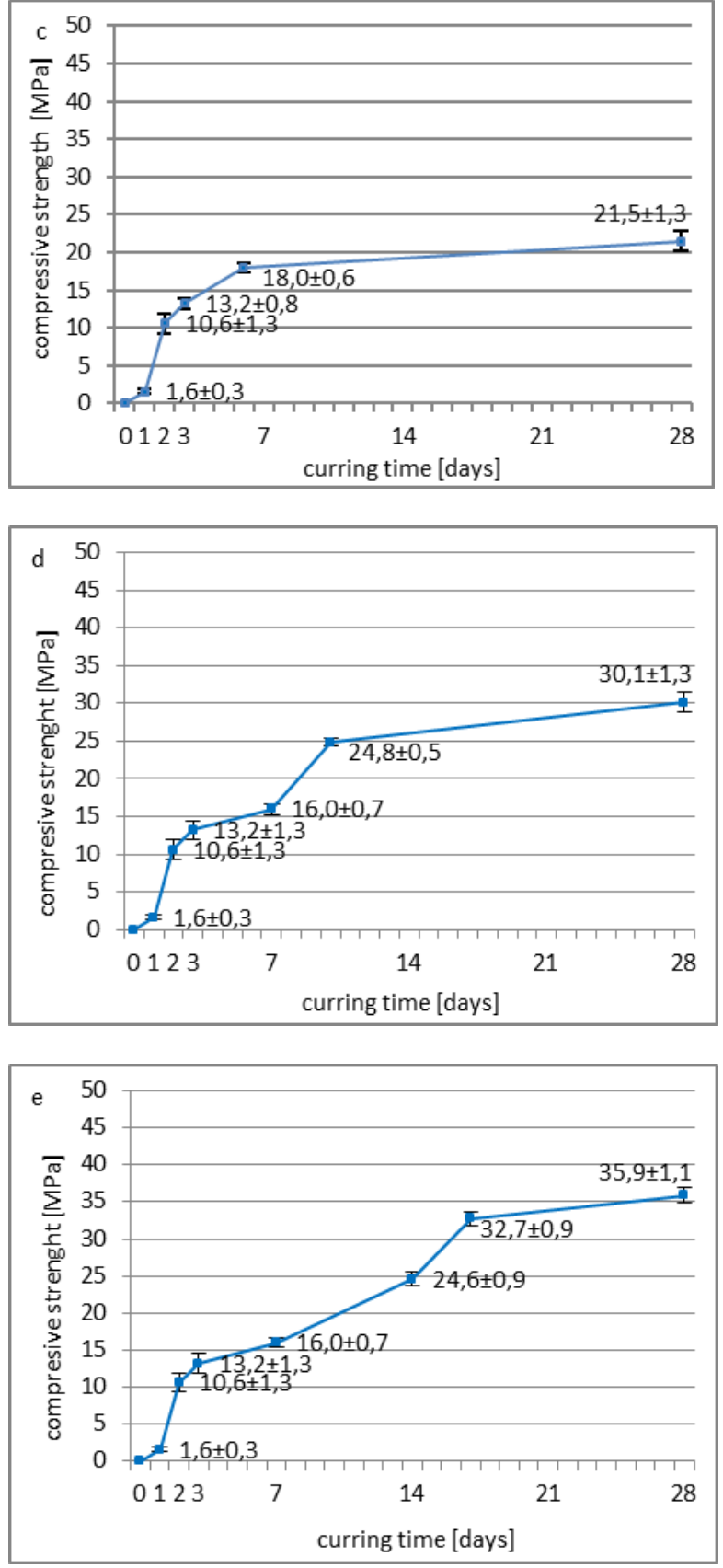

Fig. 3. Strength gain for mortar B samples subjected to variable-temperature cycles: a) cycle I, b) cycle II, c) cycle III, d) cycle IV, e) cycle V

Analysing data for mortar $\mathrm{C}$ presented on the diagrams it becomes evident that compared to samples cured at $8^{\circ} \mathrm{C}$ the entire time, lowering the temperature to $1{ }^{\circ} \mathrm{C}$ did not affect the strength reached after 28th day of curing if the samples were cured according to cycles IIV. A slight impact, close to uncertainty of the obtained results, can only be noticed when samples were cured according to cycle I. This scenario also displays a drop in strength gain rate after storage at $1^{\circ} \mathrm{C}$. This phenomenon does not occur for samples subjected to changes according to cycles II-IV, where the strength gain occurs at a rate no worse than for samples cured at $8^{\circ} \mathrm{C}$. Complete stop of strength gain after storage at $1^{\circ} \mathrm{C}$ occurs in the last of the analysed variable curing conditions - cycle V. A decrease in strength after storage 
at $1^{\circ} \mathrm{C}$ was not recorded for any of the scenarios. Furthermore, after the period of storage at $1^{\circ} \mathrm{C}$ ended and curing at $8^{\circ} \mathrm{C}$ was continued until the 28 th day, each of the cases displayed an increase in strength.
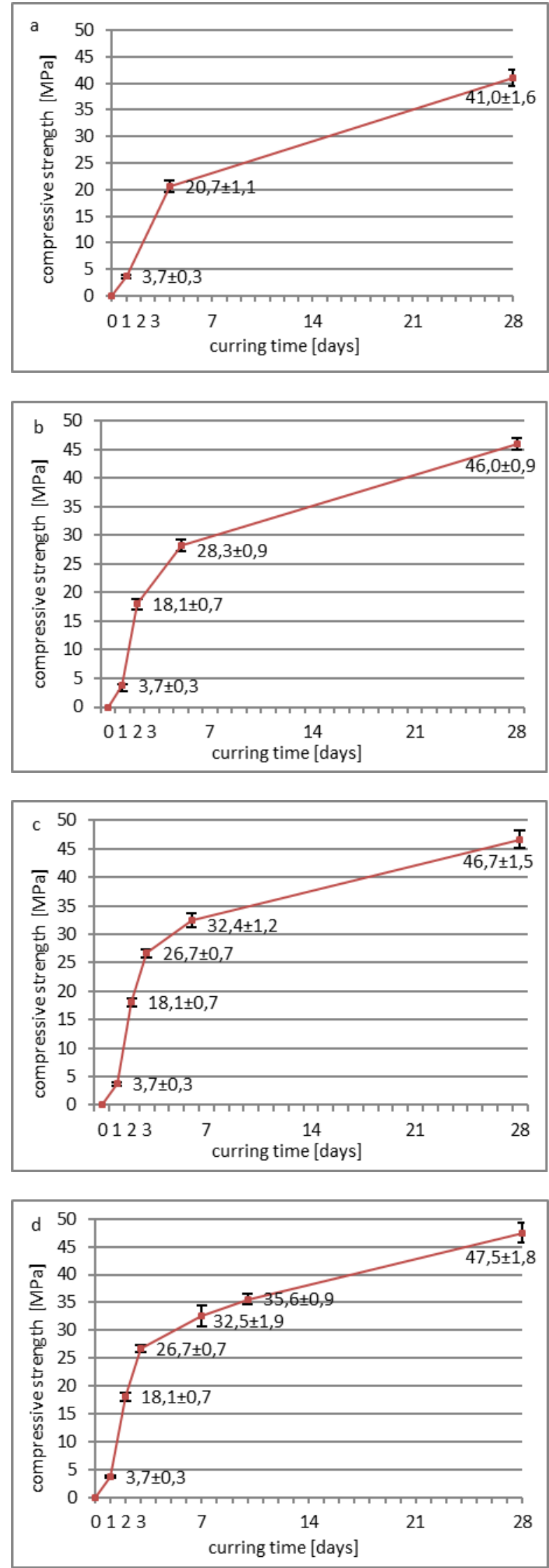

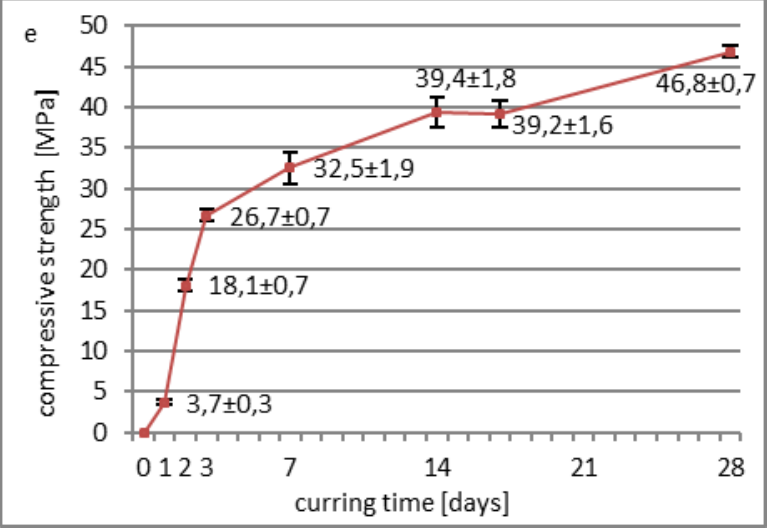

Fig. 4. Strength gain for mortar $\mathrm{C}$ samples subjected to variable-temperature cycles: a) cycle I, b) cycle II, c) cycle III, d) cycle IV, e) cycle V

Analysing test results obtained for mortar D subjected to variable cycles it can be determined that compared to samples cured at $8^{\circ} \mathrm{C}$ for the entire period, there was a decrease in strength after the 28th day in all analysed cycles. The highest reduction - by almost 15 $\mathrm{MPa}$ - was recorded for cycle I. A less severe reduction of strength, equal to $5 \mathrm{MPa}$, was observed for the other analysed variable-temperature cycles. Similarly to mortar C, mortar D also displays a drop in the strength gain rate after the storage period at $1^{\circ} \mathrm{C}$ in cycle $\mathrm{I}$. This phenomenon does not occur for samples subjected to changes according to cycles II and III, where the strength gain occurs at a rate no worse than for samples cured at $8^{\circ} \mathrm{C}$. Complete stop of the strength gain after storage at $1^{\circ} \mathrm{C}$ occurs for cycles IV and V. For product $\mathrm{D}$, similar to products $\mathrm{B}$ and $\mathrm{C}$, no decrease in strength after storage at $1{ }^{\circ} \mathrm{C}$ was recorded for any of the scenarios. Furthermore, after the period of storage at $1^{\circ} \mathrm{C}$ ended and curing at $8^{\circ} \mathrm{C}$ was continued until the 28 th day, each of the cases displayed an increase in strength.

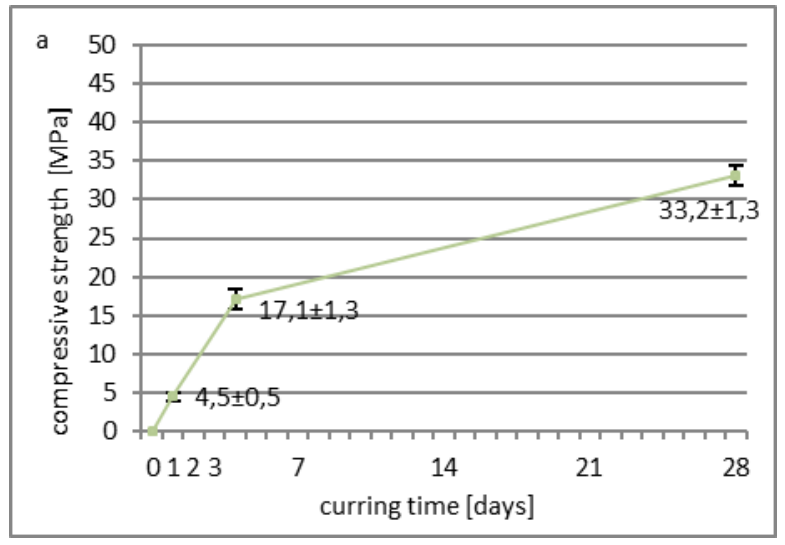



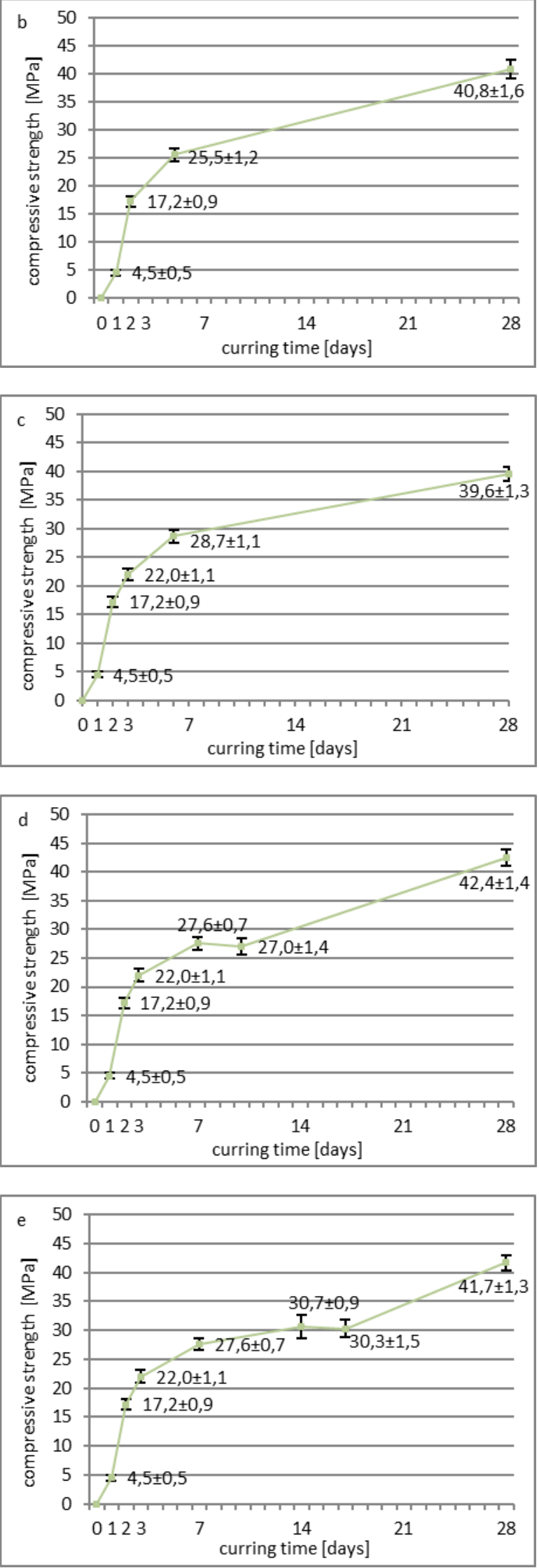

Fig. 5. Strength gain for mortar D samples subjected to variable-temperature cycles: a) cycle I, b) cycle II, c) cycle III, d) cycle IV, e) cycle V

\section{Summary of test results}

The obtained test results indicate a significant impact of lowered temperature present in the curing period on the gain of compressive strength over time.

All three analysed mortars, as per the manufacturer's declaration, may be used in temperature range of 5$30^{\circ} \mathrm{C}$.

Compressive strength test of mortar B samples cured at $8^{\circ} \mathrm{C}$ shows an adverse influence of the lowered temperature on the tested parameter. Despite a rapid increase in strength value (in particular in the early stages of curing), samples cured at lowered temperatures displayed lower strength as compared to samples cured in laboratory conditions, at each time point for which test were performed. Furthermore, despite extending the curing period, the product does not reach characteristics which were recorded for samples cured at $21^{\circ} \mathrm{C}$, and the difference was c. $15 \mathrm{MPa}$. A clear reduction of characteristics, considering tests carried out for both cases after 28 days, also causes the condition stated in standard PN-EN 1504-3 for class R4 to not be met, and the product only meets requirements for class $\mathrm{R} 3$ if the uncertainty of obtained results is not factored in. Extending the cure time effects an increase in parameters, but it does not allow to change the classification of the mortar, but only to meet the requirements for R3 class mortars with a large margin. In all preprogrammed variable-temperature cycles mortar B displayed a gain in strength throughout the curing period, and after the end of the period of storage at $1^{\circ} \mathrm{C}$ and continuing curing at $8^{\circ} \mathrm{C}$ until the 28 th day, each of the cases showed an increase in strength. Compressive strength values obtained after 28 days of curing for mortar B, following the conditions of all cycles, were so low that they cannot be classified as class R4 in any of the cases, and in the case of curing under cycle II and III conditions they can only be classified as R2, which means that its classification changes from mortar fit for structural repairs to mortar fit for non-structural repairs. Lowering the curing temperature for product $\mathrm{B}$ to $8^{\circ} \mathrm{C}$ or subjecting it to variable-temperature cycles described above caused the product's class to be lowered from R4 to R3, in some cases even to R2.

Compressive strength tests of mortar $\mathrm{C}$ carried out for lowered temperature, where the curing temperature was equal to $8^{\circ} \mathrm{C}$ throughout the entire curing period showed that lowered temperature has a negative impact on strength gain over time. Despite a rapid increase in strength value, samples cured at lowered temperatures displayed lower strength as compared to samples cured in laboratory conditions, at each time point for which test were performed. Furthermore, despite extending the curing period, the product does not reach characteristics which were recorded for samples cured at $21^{\circ} \mathrm{C}$, and the difference was c. $10 \mathrm{MPa}$. A considerable reduction of characteristics, considering tests carried out for both cases after 28 days, also causes - similarly to mortar B the condition stated in standard PN-EN 1504-3 for class R4 to not be met, and the product only meets requirements for class R3. However, there is a positive phenomenon consisting in continued increase in strength 
over time, which allows the mortar to reach strength enabling it to be placed in R4 class again after 42 days. Subjecting the samples to variable-temperature cycles also caused a decrease in the compressive strength after 28 days of curing. Samples cured under any of the preprogrammed variable cycles displayed gain in strength throughout the entire curing period. Despite lower characteristics as compared to the samples cured at laboratory temperature the entire time, the product cured according to the pattern of cycles II-V reached a strength level which allowed it to be included in R4 class after 28 days. The situation was different for cycle I, where the drop in strength was so significant that the product could only be classified as R3. Lowering the temperature or using preprogrammed variable-temperature cycles effected a lowering of the product's class down to R3, considering the compressive strength test results obtained when the product was cured according to cycle I conditions.

Compressive strength test of D mortar samples cured at $8^{\circ} \mathrm{C}$ shows an adverse impact of lowered temperature on the tested parameter. Similar to product C, despite a rapid increase in strength value, samples cured at lowered temperatures displayed lower strength as compared to samples cured in laboratory conditions, at each time point for which test were performed. However, in this case extending the curing time to 42 days allowed to reach the same parameters as the samples cured for 28 days in laboratory conditions. What is more, the strength obtained after 28 days of curing at a lowered temperature was good enough to classify the product as R4. Subjecting the samples to variable cycles, similar to mortar C, caused a decrease in compressive strength after 28 days of curing. In all preprogrammed variabletemperature cycles mortar D displayed a strength gain throughout the curing period. The value of mortar D's compressive strength achieved after 28 days of curing, in all of the cycles, was so low that it does not allow to classify the product as R4 class, but only as R3. The greatest loss of strength was recorded for cycle I. Lowering the temperature or using preprogrammed variable-temperature cycles effected a lowering of the product's class down to R3, considering the compressive strength test results obtained when the product was cured according the conditions of any of the variable cycles.

Two of the three analysed mortars proved that lowering the temperature from $8^{\circ} \mathrm{C}$ to $1^{\circ} \mathrm{C}$ for three days impacts the end strength negatively as compared to storing them at $8^{\circ} \mathrm{C}$ the entire time, if it occurs after the 1 st day of curing. Such a negative impact may in some cases occur if the temperature is lowered later (after 2, 3, 7 or even 14 days).

\section{Conclusions}

The tests have shown a negative impact of lowered temperature present during curing of polymer-cement repair mortars for concrete structures on the analysed parameters, i.e.: loss of compressive strength, as compared to samples cured in laboratory conditions, to an extent which lowered the product's class,

$>\quad$ in some cases inability to achieve the strength equal to that of samples cured at laboratory conditions despite extending the cure time.

Lowering the temperature in the initial stage of the curing period (in the first three days) does not completely stop the compressive strength gain.

\section{References}

1. L. Czarnecki, P. Łukowski, A. Garbacz, Naprawa i ochrona konstrukcji betonowych. Komentarz do PN-EN 1504, Wydawnictwo Naukowe PWN S.A. (Warszawa 2017)

2. L. Czarnecki, P. H. Emmons, Naprawa i ochrona konstrukcji betonowych, Polski Cement Sp. Z o.o., (Kraków 2002).

3. Wykonywanie robót budowlanych w okresie obniżonej temperatury. Wytyczne, Instrukcja nr 282/2011, Instytut Techniki Budowlanej, (Warszawa 2011)

4. J. Jasiczak, Technologie budowlane II, 7. Wykonywanie monolitycznych robót betonowych w warunkach niskich temperatur, Politechnika Poznańska (Poznań 2003)

5. E. Haustein, M. Pawelska-Mazur, Inżynier budownictwa, Domieszki przeciwmrozowe $i$ ich stosowanie $w$ niskich temperaturach, 2, 60-65 (2017)

6. V. Ezerskiy, M. Lelusz, Budownictwo i Inżynieria Środowska, , Wpływ domieszek przeciwmrozowych i klasy cementu na wytrzymałość zapraw cementowych, 1 (2010)

7. A. Kaczmarek, Procedia Engineering, , The influence of lowered air temperature during setting of construction mortars on their technical parameters, 193 (2017)

8. M. Husem, S. Gozutok, Construction and Building Materials, The effects of low temperature curing on the compressive strength of ordinary and high performance concrete, 19 (2005)

9. G. Bajorek, Inżynier Budownictwa, Roboty betonowe $w$ okresie zimowym - czy domieszki rozwiążą problemy?, 11, 65-69 (2012)

10.1.S. S. Heng Wpływ obniżonej temperatury na rozwój wytrzymałości betonu, Dni Betonu, (Wisła 2010) 